\title{
1
}

\section{An Adventure on POD's High Cs: Culture, Creativity, and Communication in the Academy: A Humanist Perspective}

Keynote address given at the November 2004 POD Conference in Montreal, Quebec.

James Downey

University of Waterloo

First, let me say how honored I feel to have been invited to give a keynote address at this conference. I admire POD (Professional and Organizational Development Network in Higher Education) and believe the work its members do in faculty development and the enhancement of teaching and learning is vital to the ability of our universities to meet the challenge of contemporary society and, even more important, to fulfill our timeless purpose of educating men and women into better, fuller, and more satisfying lives.

When it comes to speeches, university presidents have a reputation to live down to. I assume, however, that if the organizers of this conference had wished a dog and pony show they would have invited an animal trainer, not an ink-stained humanist who has spent nearly all his adult life dispensing words, first as an academic, then as an administrator. And I emphasize the two modes. For, to paraphrase Saint Paul: When I was an academic I spake as an academic, I thought as an academic, I understood as an academic. But when I became an administrator I put away academic things. Now I see through a glass darkly and speak only in generalities.

Culture, communication, and creativity: Just to say it kind of sucks all the air out of the room. The primary colors of meaning have run so badly in all 
these nouns that each has become a semantic Rorschach. Most thinking people prefer to avoid them.

Take culture, for example. The Closing of the American Mind by Allan Bloom (1987) was, you will painfully recall, a requiem for the academy. Compared to the high ideals of Plato's Lyceum, the modern university was a world of fallen arches. Rubble had accumulated at the mouth of the cave inhabited by self-serving professors and time-serving students. The culture of the academy had been corrupted. The word culture itself, he said, had become part of "empty talk, its original imprecision now carried to the point of pathology."

Anthropologists can't define it although they are sure there is such a thing. Artists have no vision of the sublime, but they know culture (i.e., what they do) has a right to the honor and support of civil society. Sociologists and the disseminators of their views, the journalists of all descriptions, call everything a culture - the drug culture, the rock culture, the street gang culture, and so on endlessly and without discrimination. (p. 184)

Creativity, according to Bloom, has fared no better. The concept has been trivialized by indiscriminate application: "[A word] meant to describe and encourage Beethoven and Goethe [is] now applied to every school child. It is in the nature of democracy to deny no one access to good things" (p. 183). "Thus," Bloom concludes of the use of both culture and creativity, "what was intended as an elevation of taste and morality has become grist for our mill while sapping the mill's foundation" (pp. 183-184). I can only conclude that Professor Bloom is spinning like a top in his grave as we open this conference.

Whatever one might think of the thesis of Bloom's famous book, it is hard not to grant his point about the leaching of meaning out of these two ubiquitous words, culture and creativity. (What he might have said about communication, had he thought to anatomize it, is not hard to imagine.) Others, who do not share Bloom's opinion of the academy, have agreed with him. Stephen Greenblatt (2004), author of a splendid new book on Shakespeare, said that culture "is a term that is repeatedly used without meaning much of anything at all, a vague gesture toward a dimly perceived ethos" (p. 225).

And yet, and yet, we cannot avoid using those words. In fact, truth to tell, we love 'em. We love their elasticity, their malleability. We love the way they expand and contract to accommodate whatever cargo we want them to carry. Perhaps it's too late to try to impose any kind of lexical discipline on them, but it does seem necessary, at the beginning of a conference that has chosen these words for its title, that we should reflect on their provenance. 
Culture and creativity, as secular concepts at least, have their origins in ideals of human freedom and potential forged during the Enlightenment. Both words speak to a humanistic transcendence in human intelligence and character, religious transcendence having given rise to too many blood feuds in the not-too-distant past. Both words were intended to elevate human accomplishment and self-esteem: the one collectively, the other individually. Together they represented both the means of production and the finest finished products of the human mind: "The best that is known and thought in the world" (p. 17), as Matthew Arnold (1865) would put it in his Essays in Criticism a century later.

But a caveat. In one sense culture and creativity are products of Enlightenment philosophy; in another, they were a protest against it. A product, because they grow out of a more optimistic view of humans and what they can achieve both individually and collectively. A protest, because together they helped to counterbalance the intellectual hegemony of materialistic, deterministic science which, for all the technological progress it made possible, seemed to strip humans of their claims to uniqueness and freedom. The twin concepts of culture and creativity were an affirmation that people were beings of nurture, not just creatures of nature. And on this there was a multilingual and multinational consensus: Rousseau and Voltaire, Locke and Hume, Paine and Jefferson, not to mention the man who likely coined the word culture, Immanuel Kant, all contributed to the ideas of progress and freedom and the right to dissent-in other words, of individual and collective agency and responsibility - on which modern democratic society was built.

And with it the modern university, for the university as we have inherited it is also a creature of the Enlightenment, and the academy's broad aims are entirely resonant with Enlightenment ideals. As the unofficial poet laureate of American higher education, Bart Giamatti (1990), once put it:

The university is something made, not born, cradling those individual acts of shaping that it figures forth. It is our culture's assertion that what is made by the mind has value and can convey values. Thus the university, rooted in history, open to every new impulse, insists on its centrality to culture and on its uniqueness. Thus it is so powerful and so fragile, the foe of the merely random, insisting on order while urging freedom, convinced that the human mind, out of nature, can fashion shapes and patterns nature never bore, and convinced that it is prime among the artifacts. (p. 49)

To the extent that culture and creativity speak to the primacy of the acquired over the natural, they speak to the essence of the university as it has 
developed in the years since the Enlightenment. In fact, I would argue that it is those twin concepts, culture and creativity, that, when properly understood, provide us with our most unique and important raison d'etre.

"When properly understood" includes their relation to the primary instrument of both culture and creativity: language-which also happens to be the primary instrument of communication. Let's look at our triumvirate of high Cs in reverse order, perhaps the better to understand how together they define what is most essential and inspiring in what we do.

\section{Communication}

Communication may have other connotations but it begins and ends with language. The study of language is in the first instance, and above all, a quest to understand what is most definingly human, that which sets us most distinctively apart from the rest of animal nature. To study language and its products, therefore, is to explore the complexity and diversity of our minds and emotions. What is the relation between language and culture? Between language and ethnicity? Between language and creativity? Between language and religious experience? Between language and critical judgment? Between language and feeling? What does it mean, since we're in Quebec, to speak of linguistic rights? To what extent does the language we speak and write condition perception and shape experience? What are syntactic and grammatical structures and how are they learned? Under what social and political conditions does language become debased, and what is the consequence of that debasement? How can words be combined to produce aesthetic pleasure? Why do words wound? How can words heal?

Such questions are of interest not just to professional humanists but also to all who teach, learn, or work in universities. We sometimes hear language referred to as a vehicle of communication. And it is that, of course. But it's much more. It is the primary means for discovering what we think and feel. The relationship of language to thought is not that of dress to body but of body to soul.

A humanistic interest in language goes beyond the attempt to understand how it works, to a concern for the way in which it is used. To think and speak and write clearly are important to self-expression; they are also the precondition of effective citizenship in a democratic society. They are as well, and increasingly, important to career success in a knowledge economy. Facility with language is to some degree a gift, but it is also an art that can be taught, learned, and cultivated. 
I am not one of those who believes that there has been some recent fall from grace in the quality of writing and speaking of the young, but I know there are forces at work-some social, some technological, some pedagogical-that militate against clear, direct, and effective writing and speaking. This is as true in our universities as in society at large. Some of it is manifest in what Richard Dawkins (2003), in A Devil's Chaplain, has called "metatwaddle," the process by which an academic subject expands to fill the vacuum of its intrinsic simplicity. He explains:

Physics is a genuinely difficult and profound subject, so physicists need to-and do-work hard to make their language as simple as possible.... Other academics ... want to be thought profound, but their subject is rather easy and shallow, so they have to language it up to redress the balance. (p. 51)

This may not be the whole truth; there is, however, an embarrassing measure of truth in it.

But it's not just the obscurantism of academics; it's the prophylactic prose that is the warp and weft of bureaucracies everywhere, prose that is designed to prevent meaning from seeping through. As I say, bureaucratic prudence, in universities as much as anywhere, fosters reliance on such language, but let there be no mistake about it, it has a debilitating effect on culture and community alike. The stream of our public discourse is often eloquent without being articulate, a muddy trickle of clichés and half-truths. Many in our society make a handsome living by manipulating and distorting language. Universities have a special responsibility for ensuring the wellsprings of language and communication are purified by disciplined study and disciplined usage.

\section{Creativity}

It is expected of universities that they should celebrate the great works of human creativity in all their multifarious originality. For Professor Northrop Frye (1988), the purpose of education is the training of the imagination so that we can create out of the world we live in a picture of the world we wish to live in. Frye wasn't, of course, talking about some minor pictive or fictive faculty of the human mind, but about the power we all possess to go beyond the constraints of our lives and work and envision a better society, a better world.

Every person with any function in society at all will have some kind of ideal vision of that society in the light of which he operates. One 
can hardly imagine a social worker going out to do case work without thinking of her as having, somewhere in her mind, a vision of a better, cleaner, healthier, more emotionally balanced city, as a kind of mental model inspiring the work she does. One can hardly imagine in fact any professional person not having such a social model-a world of health for the doctor or of justice for the judge-nor would such a social vision be confined to the professions.

It seems to me in fact that a Utopia should be conceived, not as an impossible dream of an impossible ideal, but as the kind of working model of society that exists somewhere in the mind of every sane person who has any social function at all. (p. 70)

Is this a fantasy world, a gauzy abstraction? On the contrary, I believe, with Frye, that it is the real world, the only abiding, dependable world. Consider the so-called real world for a moment. I was born just at the outbreak of World War II. Here, as described by Frye, is how it was then:

Japan was a totalitarian enemy and China was a bourgeois friend, the King of England was Emperor of India, Nazi Germany ruled the most powerful empire the world has ever seen.... When we look back on that world we realize that what we are living in, the world of current events and news, is actually a kind of phantasmagoria. (p. 93)

Contrary to the usual notion, the real world is the one created by education, and thus "it is not the relation of education to the world that matters, it is the relation of the world to education" (p. 95).

I believe, with Frye, that it is the empowering of this idealism that is the overarching purpose of our universities. But, to repeat and reinforce the point, the end of such study of the works of human creativity is not to stand in awe of the genius of a few great people, but to help educate our own and our students' minds so that we and they are less gullible, less susceptible to slick and facile assumptions and beliefs; to build standards of judgment and taste by which to measure our society and culture; to render our students and ourselves more our own men and women, less vulnerable to political and commercial hucksterism, less comfortable with clichés and cant, more alive to life's possibilities for achievement and service.

Does all this sound utopian? I would hope so. After the kind of dystopian century we have recently exited, and given the way we have begun a new one, we are not in danger of overdosing on optimism anytime soon. Utopias of course do not exist. That's the point of them. They are not strategic plans for political implementation, but expressions of unreal possibility, meant to stir hope and 
spur action, rude intrusions of creativity and ideals into human thought and affairs. Our universities should be rain forests for the growth of utopian dreams, providing the culture, the context, the communication, the connectivity, and the creativity to build the society and world we want to live in.

\section{Culture}

All human societies exist within an envelope of culture-of social, legal, and religious practices that, for the most part, are distilled into words. Culture has many expressions but our common understanding of the term takes three forms. There is culture as lifestyle, the way people dress or prepare food or dance. It will not take you long in Montreal to observe that a distinctive culture in that sense is alive and well in Quebec. Then there is culture as a common heritage of historical memories and customs shared through a common language. There are varying translations of the inscription you will see on Quebec license plates, je me souviens (I remember), but its deepest resonance is with culture in this second sense. Finally, there is culture as the form of what is genuinely created by a society in its literature, its art, its music, its science, its architecture, its engineering. While universities should and do provide for the study of the first two kinds of culture, it is the advancing of this third kind that lies at the heart of the university's purpose.

At the center of culture in this sense is a concern for how people live, the purposes and standards they set for themselves, the qualities and values to which they attach significance, and the principles by which they have sought and seek to give meaning to their lives and order to their communities. The mode and mood of inquiry are interrogative. Whence arise our notions of good and evil, right and wrong? By what criteria should we evaluate systems of thought, courses of action, methods of governing, works of art, each other? What other value systems and symbols have evolved in other times and places, and how may a knowledge of them clarify and enrich our own? What do we need to know and to do-in this time, in this place-to live ethically and to exercise our full rights and responsibilities in our private and public lives?

There's a story that, if apocryphal, still bears repeating. Sometime in the 1930s Albert Einstein was giving an examination to some of his Ph.D. students. As he was passing out the tests, his assistant pulled him aside to inform him that a terrible mistake had been made. It appeared that Einstein was passing out the same test he had given them once before. "That's all right," he said and smiled. "The questions may be the same, but the answers have all changed." The answers to scientific questions do indeed change, and sometimes very fast. In 
some other spheres of human endeavor the concept of progress does not apply in the same way, but there too it is essential to ask the timeless and telling questions, refining and rephrasing them to fit our current preoccupations and the state of knowledge we have arrived at.

The primary mission of the university, I believe, is not to train (though training is essential to all learning) but also to educate; not to prepare students for jobs (though that in itself is noble) but to make them wiser and more discerning people. And this is true for all students, even those learning the technical and mental skills of a profession. I like the way Cyril Belshaw (1974) put it in Towers Besieged:

A university is only justified in giving a medical or engineering, or any other, degree, if in the process the doctor or engineer has learned to question and inquire, to exercise relevant intellectual and moral judgment, and to add to knowledge if the opportunity and circumstances of his [or her] career permit. This means that the university has helped to develop [a student's] powers of intellectual awareness, ... to know what is needed to provide answers (as distinct from jumping to conclusions or accepting what one is told); and to be mature, disciplined and wise in making judgments. (p. 22)

A bit idealistic no doubt. But "without a vision the people perish." And certainly, without a sense of its higher purpose the university loses what most makes it unique among our social institutions.

In Alistair Cooke's (1952) One Man's America, there is a story that seems appropriate here. On the 19th of May, 1780, in Hartford, Connecticut, the skies at noon turned from blue to gray and by mid-afternoon had blackened over so densely that, in that more religious age, people fell on their knees and begged a final blessing before the end came. The Connecticut House of Representatives was in session, and as some of the delegates fell down in the darkened chamber and others clamored for an immediate adjournment, the speaker of the house, one Colonel Davenport, came to his feet. He silenced the din with these words: "The Day of Judgment is either approaching-or it is not. If it is not, there is no cause for adjournment. If it is, I choose to be found doing my duty. I wish, therefore, that candles may be brought."

What our universities need most of all at the moment-more than we need new facilities or larger appropriations or better performance indicators or even, God forgive me for saying so in this company, better faculty development programs, important as all of these are-are more enthusiastic and dedicated candle-bringers: people who believe with conviction in human agency, who believe we are not trapped in systems of thought or feeling or 
governance which we cannot change, who believe that ideals of justice and equality - and their affiliates, liberty and learning - still resonate with people all over the world. The change and the excellence we seek will not come about by grand design but through the countless daily acts of people who can look beyond the university's utilitarian function to catch a glimpse of its deeper culture and higher possibilities.

So what if those who learn, teach, research, and serve in the university too frequently fall short of the standards implicit in that deeper culture? A Montrealer, Leonard Cohen (1993), had the best answer to that: "Ring the bells that still can ring, / Forget your perfect offering. / There is a crack in everything, / That's how the light gets in" (p. 373).

Our sustained fascination with Leonard Cohen (at 70 he is having yet another renaissance) is evidence that culture may be mediated not only by the arguments we make, but by the songs we sing and the stories we tell. In the fall 2002 issue of The Presidency, Robert Birnbaum said that the challenge of universities in our time is not to argue a better case but to tell a better story. Stories compete with stories in the marketplace of narratives. And there is no shortage of competing narratives about the role of the contemporary university. Some portray an institution standing in very much the same relationship to its users as banks, supermarkets, and utility companies do to theirs, providing convenient, dependable, and quality service. Some tell of an institution that is already past its best-before date and will largely disappear within the next generation. They are simplistic narratives, but nonetheless effective for that. They may or may not be true, but they resonate widely.

Birnbaum cautions, "you cannot dispel a narrative merely by criticizing it or presenting logical arguments against it. A narrative can be displaced only by another narrative that is as easy to understand and tells a better story" ( $p$. 38). Where do we get better, more compelling narratives? Birnbaum suggests we start with the past.

Our narratives once told of education for democracy, for social justice, for the whole person, for the perpetuation of civilization. That is what people came to believe colleges and universities did.... Our narratives now increasingly talk about being the engines of the economy. We are, of course, but I don't believe that a utilitarian narrative alone excites the imagination of the public, or commits faculty, staff, or administrators to their institution and its success, or connects the university to our deepest human needs. (pp. 37-38)

As I was writing this address it was announced that Wangari Maathi, African environmentalist and women's rights crusader, was the 2004 winner 
of the Nobel Peace Prize. I quote from an account printed in the Globe and Mail on October 9, 2004: "Mrs. Maathi's husband, a politician, divorced her in the 1980 s on the grounds that she was 'too educated, too strong, too successful, too stubborn and too hard to control'" Let me repeat that: "too educated, too strong, too successful, too stubborn and too hard to control." What a narrative is inherent in that!

Listen again to Northrop Frye (1969):

But it seems to me that the university is a kind of Moses, who comes to people stuck in Egypt, trying to make bricks without straw, and says to them: "I think I can get you out of this, if you have the intelligence and persistence to go with me. It's a long and dusty walk, one step after another: it will take forty years and you will often lose your way. I can take you to the boundary of a better country. It belongs to you; it's your home; all you have to do is enter and take possession. But I will not go with you, because I have to go back to Egypt for more slaves. (p. 67)

$O$, to be able to catch a glimpse of that profoundly liberational and celebrational vision from time to time, to feel that this is the cause of which we are a part, this is the culture we are creating; this is the narrative we are asked to communicate; to sense our pulses quickened and our spirits lifted by the realization that all around us fresh insights are being discovered, minds illumined, and lives liberated by the knowledge and skills being imparted, by people like us.

\section{References}

Arnold, M. (1865). The function of criticism at the present time. In Essays in criticism (pp. 1-41). London, England: Macmillan.

Belshaw, C. S. (1974). Towers besieged: The dilemma of the creative university. Toronto, Canada: McClelland and Stewart.

Birnbaum, R. (2002, Fall). The president as storyteller: Restoring the narrative of higher education. The presidency, 33-39.

Bloom, A. (1987). The closing of the American mind. New York, NY: Simon \& Schuster.

Cohen, L. (1993). Anthem. In Stranger music: Selected poems and songs (pp. 373-374). Toronto, Canada: McClelland and Stewart. 
Cooke, A. (1952). One man's America. New York, NY: Alfred A. Knopf.

Dawkins, R. (2003). A devil's chaplain: Reflections on hope, lies, science, and love. New York, NY: Houghton Mifflin.

Frye, N. (1969). The ethics of change. Toronto, Canada: Canadian Broadcasting Corporation.

Frye, N. (1988). On education. Toronto, Canada: Fitzhenry \& Whiteside.

Giamatti, A. B. (1990). A free and ordered space: The real world of the university. New York, NY: W. W. Norton \& Company.

Greenblatt, S. (2004). Will in the world: How Shakespeare became Shakespeare. New York, NY: W. W. Norton \& Company. 